\title{
Sawdust ash as an inhibitor for reinforcement corrosion in concrete
}

\begin{abstract}
An evaluation of the use of sawdust-ash (SDA) as an inhibitor for reinforcement corrosion in concrete has been investigated. The results obtained showed addition of SDA to concrete can be effective in the control of corrosion. The advantages are numerous. One of such is to do with the health of the environment where timber industries are located. When used as a pozzolanic material, SDA improved porosity and imparted strengths to the concrete. The experimental results showed that carbonation depth and weight loss, are reduced by approximately $24 \%$ and $43 \%$ respectively, and therefore the process of corrosion, delayed.
\end{abstract}

Keywords: corrosion, sawdust ssh, porosity, pozzolanic, sodium sulphate, nitric acic
Volume I Issue 3 - 2016

\author{
Augustine U Elinwa,' Sani Abdulkadir² \\ 'Department of Civil Engineering, Tafawa Balewa University, \\ Nigeria \\ ${ }^{2}$ Department of Civil Engineering, Ibrahim Badamasi Babangida \\ University, Nigeria
}

Correspondence: Augustine $U$ Elinwa, Department of Civil Engineering, Tafawa Balewa University, Nigeria, PMB 0248, Email auelinwa@gmail.com

Received: November II, 2016 | Published: November 30, 2016

\section{Introduction}

The deterioration of reinforced concrete structures remains a major problem with the cost of repairing or replacing deteriorated structures becoming a major liability in many countries - Nigeria is no exception. Corrosion protection systems used for reinforced concrete structures include the use of corrosion-inhibiting admixtures, epoxy-coated reinforcing steel, water proofing membranes, penetrants and sealers, galvanized reinforcing steel, electrochemical removal of chlorides, and cathodic protection. ${ }^{1}$ Corrosion-inhibiting admixtures may influence concrete properties such as the compressive strength, elastic modulus, etc and therefore, the need to determine their effects as inhibitors becomes very paramount.

Sawdust ash (SDA) is one of the admixtures tested for this purpose, and characterized for possible use as an inhibitor. Elinwa and $\mathrm{Sani}^{2}$ have published preliminary results on SDA- OPC concrete. Some of their findings are highlighted in this work. The microstructure and durability characteristics of this material (SDA) as it affects concrete and its hydration process are presented in Figures 1 to 6 and discussed as below. ${ }^{2}$

I. SDA was effective in controlling the porosity of the concrete and as such imparts strength on the concrete.

II. The evaluation showed that by using SDA the amount of un-hydrated cement was drastically reduced as the curing progressed. The implication of this is that the quality of the concrete material is enhanced.

The levels of $\mathrm{Ca}(\mathrm{OH})_{2}$ that were produced with age drastically reduced. This is because SDA went into secondary reaction with the excess $\mathrm{Ca}(\mathrm{OH})$, produced during hydration process to form $\mathrm{C}-\mathrm{S}-\mathrm{H}$ which is responsible for strength.

When the $\mathrm{Ca}(\mathrm{OH})$, produced during the hydration process comes in contact with $\mathrm{CO}_{2}$ or ion, an acidic environment with a $\mathrm{pH}<10$ is created. This results in the initiation of steel corrosion. The corrosion reaction mechanism of reinforcement is an electrochemical reaction and its effect is the degradation of concrete structures. In the preliminary works of using SDA for durability assessment, SDA-
OPC concrete was assessed in sulphate and acid media, using $\mathrm{Na}_{2} \mathrm{SO}_{4}$ and $\mathrm{HNO}_{3}$. The monitoring was for eight weeks at sevenday intervals. The results showed that there was minimal decay to sulphate attack and aggressive decay to acid attack (Figures 5 \& 6). All specimens treated with $10 \%$ SDA showed better resistance at the end of the $8^{\text {th }}$ week. The effect of this action by SDA is that corrosion of the embedded reinforcement will be minimized if not totally eliminated. Other researchers have also studied the use of admixtures as corrosion-inhibiting materials. Valente et al. ${ }^{3}$ studied the effects of addition of fly ash and corrosion inhibitors over time on concrete strength against chloride penetration. They concluded that permeability to both water and chlorides were greatly reduced. Robertson and Newton ${ }^{4}$ researched on the performance of corrosion inhibitors in concrete exposed to marine environment. One of the conclusions reached was that the use of silica fume and fly ash showed significant reduction in the half-cell readings compared with the control specimen. Sounthararajan and Sivakumar ${ }^{5}$ took measurements on corrosion in reinforced fly ash concrete containing steel fibres using strain gauge techniques. They discovered that corrosion started in steel bars embedded in plain concrete immediately after the $7^{\text {th }}$ day but at increased fibre dosage, the intensity of corrosion was minimized. Also, there was reduction in the corrosion process as the fineness of fly ash improved the pore refinement and, thus minimized assess to deteriorating agents.

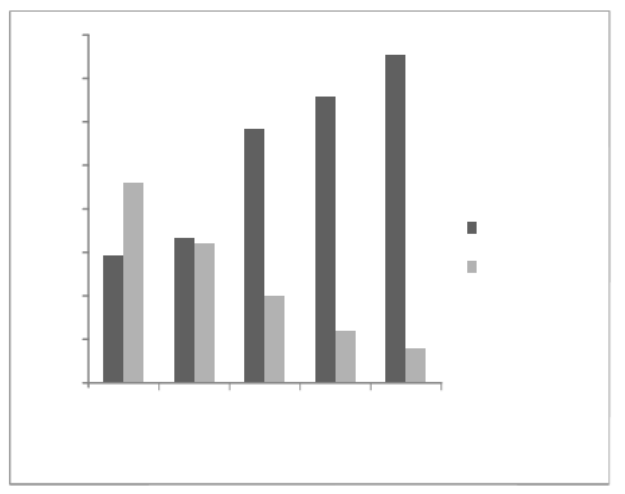

Figure I Development of compressive strength with hydration process. 


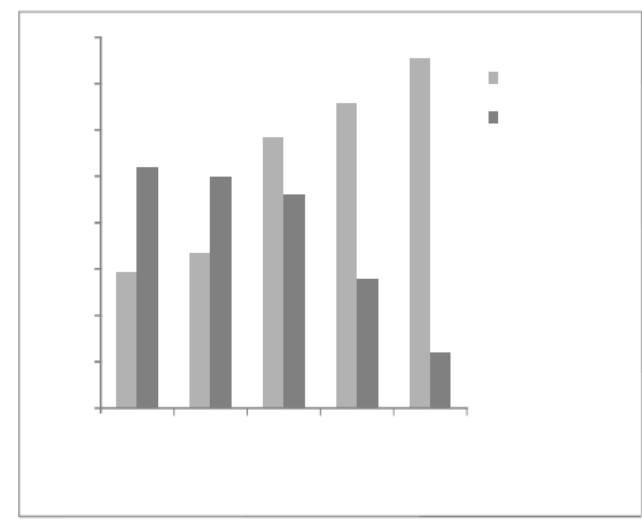

Figure 2 Development of C-S-H with compressive strength.

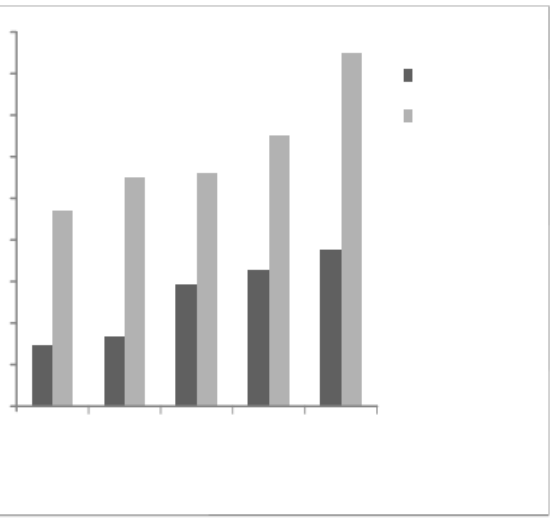

Figure 3 Development of the compressive strength with porosity.

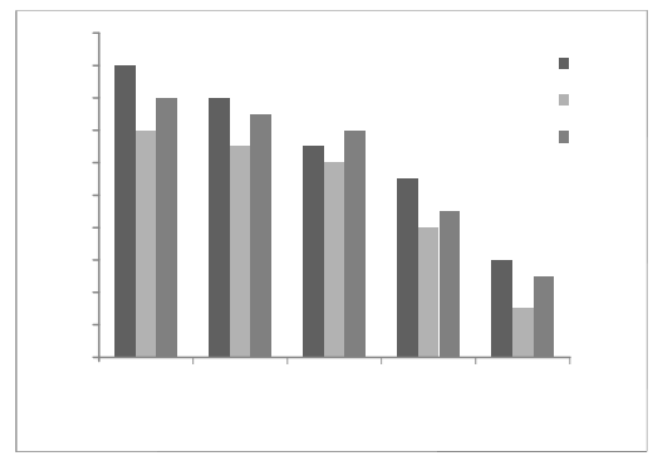

Figure 4 Development of hydration Process.

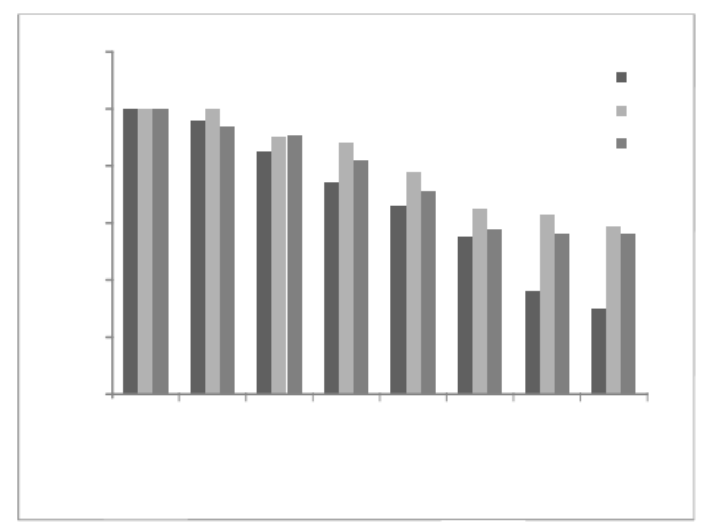

Figure 5 Decay in $\mathrm{Na}_{2} \mathrm{SO}_{4}$ medium.

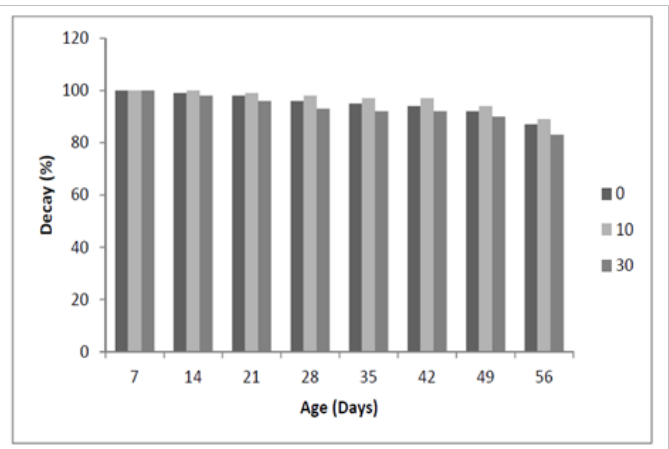

Figure 6 Decay in $\mathrm{HNO}_{3}$ medium.

The present research work is a furtherance of the development of using SDA as an inhibitor in controlling the menace of corrosion in our construction works. The same mix ratios that were used in the first part of this work ${ }^{2}$ was also used in the present work, that is - a total cement content of $375 \mathrm{~kg} / \mathrm{m}^{3}$, fine aggregate of $600 \mathrm{~kg} / \mathrm{m}^{3}$, coarse aggregate of $1115 \mathrm{~kg} / \mathrm{m}^{3}$ and $\mathrm{w} / \mathrm{c}$ ratio of 0.56 . A total of 5 (five) mixes containing SDA as replacement materials for cement in the proportions of $0 \%, 5 \%, 10 \%, 20 \%$ and $30 \%$ by weight of cement were added. The mix containing the $0 \%$ is the control mix. The physical/chemical properties of the SDA and other characteristics are contained in the earlier publication. Figure 7 is the experimental set-up used for the measurements of the following:

a. The potential measurement of steel bars embedded in concrete (Half- cell potentials)

b. The physical evaluation of corrosion by measuring weight loss of specimen after corrosion activity, and

c. The measurement of the depth of carbonation of hardened concrete specimen.

The importance of this work points to the fact that there is no universally accepted practice with regard to testing corrosion inhibitors when admixed into concrete.

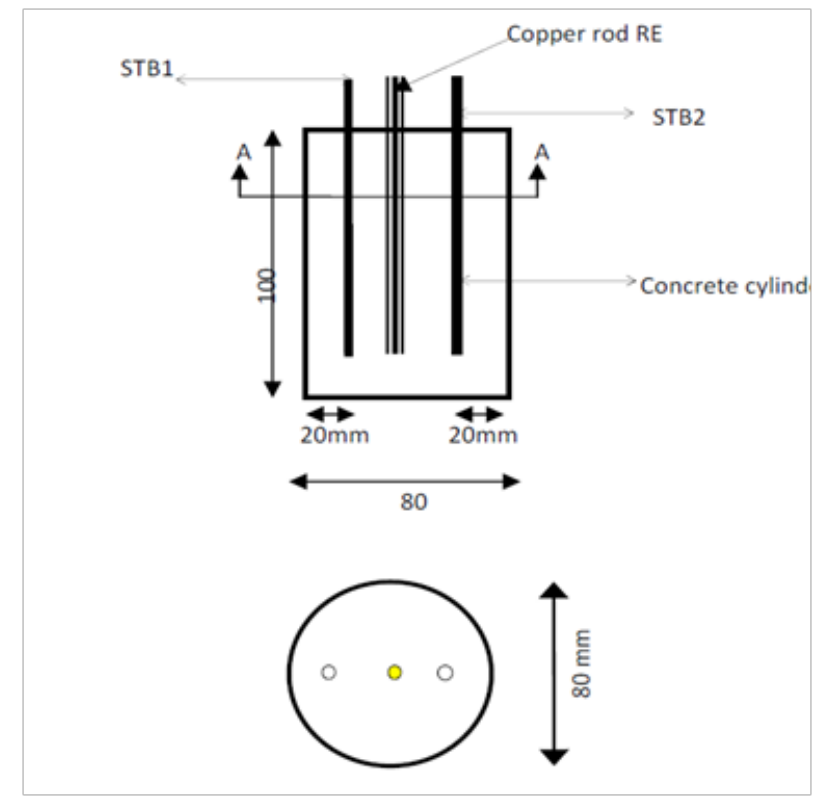

Figure 7 Experimental Set-up. 


\section{Half-cell potentials}

Corrosion is an electrochemical process and electrons flow from the site of corrosion (Anode) to the non-corroding site (Cathode). In the experimental set-up for this case (Figure 7), use was made of SDA in proportions of $5 \%, 10 \%, 20 \%$, and $30 \%$ by weight of cement as discussed earlier. The test specimens are concrete cylinders of $100 \mathrm{~mm}$ high and $80 \mathrm{~mm}$ diameter containing two $10 \mathrm{~mm}$ diameter embedded steel bars, marked STB-1 and STB-2, respectively. Copper wire cables were connected to each steel bar for the electrochemical measurements. The surface of the steel bars was thoroughly cleaned of any rust material before weighing.

The steel bars and a copper rod used as a reference electrode (RE) were embedded in each mold to a depth of $20 \mathrm{~mm}$ with a concrete cover of $20 \mathrm{~mm}$ as shown in the Figure 7 . The concrete specimens were stored under the laboratory conditions for 24 hours before de-molding and cured in water for 7 days. In order to accelerate corrosion activity under laboratory conditions, the concrete specimens were subjected to cycles of drying for 5 days and wetting for 2 days respectively in $3.5 \% \mathrm{NaCl}$ solution. The specimens were covered with epoxy resin araldite to protect the connection of steel with copper cable against corrosion.

The corrosion potentials of the steel embedded in the concrete cylinders were determined according to ASTM 876-880 beginning at the $7^{\text {th }}$ day after casting using an Arm field Corrosion Study Kit, in Chemical Engineering Programme, Abubakar Tafawa Balewa University, Bauchi, Nigeria, having digital voltmeter range of $200 \mathrm{mV}-1000 \mathrm{mV}$. Electric direct current with constant voltage of $30.6 \mathrm{~V}$ was impressed with the positive terminals of the digital voltmeter connected to the two embedded steel bars and the negative terminals connected to the copper, the reference electrode (RE). The potentials of the embedded steel bars were recorded at the end of each regime of drying and wetting periods and the average of two readings recorded at 7 days intervals for a period of 90 days. Results are shown in Table 1.

Table I Open circuit potentials

\begin{tabular}{|c|c|c|c|c|c|c|c|c|c|c|c|c|c|c|}
\hline \multirow{2}{*}{ Mix } & \multicolumn{14}{|c|}{ Potentials (mV)/(Days) } \\
\hline & 0 & 7 & 14 & 21 & 28 & 35 & 42 & 49 & 56 & 63 & 70 & 77 & 84 & 90 \\
\hline CM-00 & -175 & -208 & -242 & -252 & -265 & -272 & -291 & -320 & -355 & -380 & -469 & -494 & -565 & -595 \\
\hline CM-05 & $-|7|$ & -206 & -240 & -248 & -257 & -258 & -282 & -311 & -335 & -364 & -450 & -431 & -492 & -555 \\
\hline CM- 10 & -168 & -204 & -238 & -244 & -244 & -248 & -275 & -290 & -321 & -346 & -447 & -460 & -485 & -543 \\
\hline CM-20 & -155 & -202 & -220 & -221 & -230 & -239 & -247 & -275 & -301 & -329 & -375 & -390 & -474 & -480 \\
\hline CM-30 & -162 & -201 & -223 & -229 & -235 & -243 & -272 & -285 & -320 & -341 & -396 & -451 & -497 & -615 \\
\hline CM-00S & -169 & -165 & -168 & -170 & -195 & -246 & -255 & -276 & -283 & -366 & -375 & -387 & -396 & -490 \\
\hline CM-05S & -162 & -164 & -168 & -179 & -198 & -242 & -250 & -272 & -280 & -335 & -341 & -351 & -370 & -455 \\
\hline CM-IOS & -158 & $-|6|$ & -170 & -174 & -178 & -198 & -248 & -256 & -275 & -298 & -347 & -359 & -368 & -444 \\
\hline
\end{tabular}

\section{Carbonation depth}

Carbonation is the reaction of carbon dioxide from water or air with alkaline hydroxides in concrete. This reaction results in the reduction of the $\mathrm{pH}$ of the pore water of the concrete. At lower $\mathrm{pH}$ values of about 8.3 , the protective passive layer of the steel is removed and corrosion takes place in the presence of oxygen and moisture. The objective of the test is to evaluate the corrosion activity at steel-concrete interface resulting from the penetration of oxygen and moisture through the concrete cylinder specimens. Since the corrosion potential method has the disadvantage of producing results that are qualitative, without establishing the actual rebar corrosion rate, the carbonation depth technique could be used for a better evaluation of corrosion activities.

The carbonation depth of each concrete cylinder specimens was determined at the end of the corrosion test (90 days). The specimens were carefully split open manually using a hammer and the steel bars carefully removed from the concrete. The freshly broken surfaces were then treated with phenolphthalein indicator. The free $\mathrm{Ca}(\mathrm{OH})$ is colored pink while the red coloring indicates the depth of carbonation. An average of three measurements was taken on each steel bar and results are presented in Table 2.
Table 2 Carbonation depth and weight loss

\begin{tabular}{lll}
\hline Mix & Carbonation depth $(\mathbf{m m})$ & Wt. loss $(\%)$ \\
\hline CM-00 & 3.4 & 0.23 \\
CM-05 & 3.2 & 0.15 \\
CM-10 & 2.2 & 0.13 \\
CM-20 & 2.6 & 0.15 \\
CM-30 & 2.8 & 0.17
\end{tabular}

\section{Weight loss}

The measurement of weight loss can serve as a means of quantifying the corrosion activity in concrete structures and can be used to determine the rate of corrosion in concrete. Thus, the data generated can be modeled to predict the service life of the reinforcing bars in a corrosive environment. This test was carried out at the end of the corrosion monitoring test of 90 days. The weight losses were determined after the rusts on the steel bars were removed by 
proper cleaning using hydrochloric acid. At the end of the 90 days of corrosion test, the concrete specimens were split open and the steel bars immersed in hydrochloric acid for 15 minutes and washed with water, alcohol and acetone. The weight loss of each steel bar (STB1 and STB2) was determined by subtracting the final weight of steel from the initial weight recorded earlier before embedding in concrete. Results are shown in Table 2.

\section{Results and discussions}

Based on the classification table of ASTM C876 the data in Table 1 are further classified in Table 3, to ascertain the effectiveness of SDA in arresting corrosion. Deductions from Table 3 show that:

i. For probability of corrosion less than $10 \%$ to occur Table 3 shows that specimens treated with SDA only, are likely to start from the $7^{\text {th }}$ day and, that with SDA and NS, will start

Table 3 Likelihood of corrosion damage as a function of the corrosion potential (ASTM C876 1993)

\begin{tabular}{|c|c|c|c|}
\hline Replacement (\%) & SDA only (Days) & SDA Plus NS (Days) & Classification \\
\hline \multicolumn{4}{|l|}{$<-200 \mathrm{mV}$} \\
\hline \multirow[t]{2}{*}{0} & $<7$ & $<35$ & \\
\hline & $<7$ & $<35$ & \\
\hline 5 & & & Corrosion is Less Than \\
\hline \multirow[t]{2}{*}{10} & $<7$ & $<42$ & \\
\hline & & & $10 \%$ \\
\hline 20 & $<7$ & $<35$ & \\
\hline \multicolumn{4}{|c|}{ - $200 \mathrm{mV}$ to $-0.350 \mathrm{mV}$} \\
\hline 0 & $7-49$ & $35-56$ & \\
\hline 5 & $7-56$ & $35-70$ & Probability of \\
\hline 10 & $7-63$ & $42-70$ & Corrosion is Uncertain \\
\hline 20 & $7-63$ & $35-70$ & \\
\hline \multicolumn{4}{|l|}{$-0.350 \mathrm{mV}$} \\
\hline 0 & From 56 & From: 63 & \\
\hline 5 & 63 & 77 & Probability of \\
\hline 10 & 77 & 77 & Corrosion is $90 \%$ \\
\hline 20 & 70 & 77 & \\
\hline
\end{tabular}

\section{Conclusion}

From the evaluations carried out on the characteristics of SDAOPC concrete, we can conclude that SDA can be used to enhance the life of concrete structures.

A. The porosity of concrete was greatly improved when SDA was added to the mix.

B.S D A is pozzolanic in nature and went into secondary reaction with the hydration product of cement $\left(\mathrm{Ca}(\mathrm{OH})_{2}\right)$, to produce $\mathrm{C}-\mathrm{S}-\mathrm{H}$ which imparts strength to the concrete.

C. Possible start of corrosion from the results of the half-cell potentials showed delayed action when SDA is added and best results were at the optimum replacement level, which is $10 \%$.

Figure 8 Carbonation depth (mm) and weight loss (\%). 
D. SDA addition improved the carbonation depth and weight loss. The best results were obtained at the $10 \%$ replacement and the values are $24 \%$ and $43 \%$ respectively for carbonation and weight loss.

\section{Acknowledgements}

None.

\section{Conflict of interest}

The author declares no conflict of interest.

\section{References}

1. Pham PA, Newtson CM. Properties of concrete produced with admixtures intended to inhibit corrosion. USA: University of Hawaii; 2011.

2. Engineering and Environment. Research Report UHM/CE/01-01. 1-129. 2011.

3. Elinwa AU, Abdulkadir S. Characterizing sawdust-ash for use as an inhibitor for reinforcement corrosion. New Clues in Sciences. 2011:1-10.
4. Valente M, Bressan M, Pasqualini A, et al. The effects that fly ash and corrosion inhibitors have on increase over time of concrete strength against chloride penetration: a modular approach. The New Boundaries of Structural Concrete. Italy: Università Politecnica delle Marche Ancona; 2011.

5. Robertson IN, Newtson C. Performance of corrosion inhibitors in concrete exposed to marine environment. Concrete Repair, Rehabilitation and Retrofitting II. In: Alexander, et al. editors. London: CRC Press; 2009. p. 331-332.

6. Sounthararajan VM, Sivakumar A. Corrosion measurements in reinforced fly ash concrete containing steel fibres using strain gauge technique. Hindawi Publishing Corporation. International Journal of Corrosion. 2013;2013:7

7. http://dx.doi.org/10.1155/2013/724194.

8. Standard Test Method for Corrosion Potentials of Uncoated Reinforcing Steel in Concrete American Society for Testing and Materials. 2009. 